MEDICAL SCIENCE IN THE WAR.

SIR ANTHONY BOWLBY, at the annual general meeting of the Research Defence Society on June 26, gave an admirable little address on "Experimental Medicine and the Sick and Wounded in the War." He spoke with authority; there is no surgeon with more right to do that. But, of course, he could not do more than touch points here and there of the great subject. He took for these points typhoid, tetanu., gas-gangrene, dysentery, and trench-fever, and he began with this praise of our Army: that it had been the healthiest Army in the war, partly because "the average Briton is naturally a cleanly animal," partly because the British soldier understands a reasonable explanation, and is guided by it in daily life, and partly because our Army Medical Service, "a body of men unequalled in any other country on the face of the globe," was constantly lecturing to the combatant officers, who in their turn instructed their men in the ways of health. So it came to pass that the amount of "sick wastage" in our Army was kept low; and that is how the war was won.

If that were all, or anything like all, there would be some excuse for the foolish people who say that the health of our Army was safeguarded, not by experimental medicine, but by "ordinary sanitation." But, as Sir Anthony said, "the hygiene of to-day is based upon the experimental medicine of yesterday." It was hygiene to protect our men against typhoid and our wounded men against tetanus; but it came out of the experimental work of Nicolaier, Wright, and others; there was no possible way but that, if it was ever to come. He reminded his hearers of the vivid contrast early in the war between the British Expeditionary Force and the French Army; how France, to save herself, had to send out her Army unprotected against typhoid; there was no time to protect them; "the result was that between August $x$ and April they had as many as 60,000 cases of enteric." He might have added the not less remarkable results of the protective treatment later in the war against paratyphoid.

Next, Sir Anthony spoke of tetanus. We all remember how, in the first months of the war, our national anxiety for our men was heightened by the dreadful news that there was a great deal of tetanus among the wounded:- "At the beginning of the war in France we had a truly terrible attack of tetanus among our wounded. Everybody was surprised and alarmed. The prevalence of the disease had not been anticipated, and consequently there was no prophylactic serum in proportion to the number of troops. We could not suddenly supply them with preventive doses of serum. It had to be made. We obtained all the supplies we could get from America, but it took time. In August, September, and October, I9r4, our troops were to a great extent uninoculated, and the result was an appalling amount of tetanus. Shortly afterwards almost every man was able to be inoculated. The ratio of the number of cases of tetanus to the number of wounded was about six times as high in September, I9I4, as it was in November, and nine times as high as it was in December of the same year."

Sir Anthony spoke also of experimental medicine in relation to the study and treatment of gas-gangrene and of dysentery, and he and Capt. Walter Elliot (who seconded a vote of thanks to him) spoke of trench-fever and of those memorable experiments on self, by British and American volunteers, which proved the transmission of trench-fever by lice, and made it possible to bring down "by leaps and bounds" the evil done by the disease. Strange to think, with these facts before us, that there are so many people who still belong to "anti-vivisection" societies.

\section{EXPERIMENTAL STUDIES OF} SELECTION.

$M$ R. A. STURTEVANT has experimented (Publication 264 , Carnegie Institution of Washington, I9.8, pp. I-68, I plate) with a mutant race of the fruit-fly, Drosophila melanogaster (ampelophila), with the particular object of determining the effects of selection. The mutant character in question is known as Dichæt; it appeared in $\mathrm{I}_{9} \mathrm{I}_{5}$ in a single female which had wings extended and bent backwards near the base, and with only two dorso-central bristles instead of the usual four. This "Dichæt" character behaves as a dominant, and it appears that the factor or gene corresponding with it is located "in the third chromosome, approximately five units to the left of pink." Dichæt-flies are more variable in bristlenumber than are non-Dichæets. The variability is partly environmental, partly genetic.

Selection is generally admitted to be capable of effecting change, either gradually or sudienly, in the mean character of a mixed race, but if this be granted a number of questions arise. Does selection use germinal differences that are already present, or differences that arise during the experiment? To this the author answers that selection produces its effects chiefly through isolation of factors already present, though occasionally available mutations do arise in the course of the experiment. But if selection uses new differences, does it cause them to occur more frequently, and does it influence their direction? To this the author answers that there are no available data warranting an affirmative answer.

What selection does is to isolate genetic differences already present. The experiments made on the Dichæt-fly go to show that genes are relatively stable, not being contaminated in heterozygotes, and mutating only very rarely. There is strong confirmation of the multiple-factor view that characters may be influenced by more than one pair of genes. There are genes that modify other genes, but there is no experimental evidence that allelomorphs present in the heterozygote may influence or "contaminate" each other, so that they do not come out unchanged. The general outcome of Mr. Sturtevant's elaborate investigation is to lead us to believe that the chief role of selection is in isolating favourable combinations of genes.

\section{FUNGUS DISEASES OF ECONOMIC PLANTS.}

TTO A. REINKING (Philippine Journal of Science, vol. xiii., section A, July, 19 I8) supplies a list of fungus diseases of Philippine economic plants which will be of value to plant-growers in other tropical areas. The warmth and moisture of the climate account for the great number and destructiveness of these diseases during the wetter months of the year, and Mr. Reinking estimates that in the province in which he is specially interested at least ro per cent. of agricultural crops are destroyed by fungi. The great factors in the spread and destructiveness of fungi are the lack of proper culture, of sanitation, of pruning, and of spraying. Many of the plants concerned are widely cultivated in the tropics, and the paper has been written in order to give some idea of the prevalence of plant diseases, their causes, mode of attack, plant hosts, the amount of damage, and also the methods of control. Many of the diseases are due to fungus species new to science. The account is illustrated by twenty-two plates and fortythree text-figures.

Under the title "Seedling Diseases of Conifers" (Journal of Agricultural Research, Washington, D.C., NO. 2592 , VOL. IO3] 
vol. xv., December, I9I8), Carl Hartley, '. . C. Merrill, and Arthur S. Rhoads have made a valuable contribution to the study of forest pathology. Damping-off is the most serious disease of very young seedling conifers, and several types of the disease are described. In addition to the well-known Pythium debaryanum and Corticium vagum, species of Fusarium and Botrytis cinerea have been isolated from affected seedlings, and are believed to be able to cause the disease. Artificial cultures of the fungus indicated a marked difference in virulence between different strains, which bears little or no relation to the host from which the strain was isolated. Thus strains from spruce and sugar-beet respectively proved more virulent in inoculations on pine seedlings than did any of the strains originally isolated from pine. Losses often wrongly attributed to poor seed are caused by the fungus killing the seed or the seedling before it appears above soil; and some of the damping-off fungi may continue to kill the roots of seedlings after they develop rigid stems, so that the plant does not fall over. The latter type of trouble is sometimes confused with damage caused by excessive heat or dryness of soil.

In the Memoirs of the Department of Agriculture in India (Botanical Series, vol. ix., November, I918) W. McRae gives a detailed account of a new fungus disease (Phytophthora meadii) of a rubber plant, Hevea brasiliensis. This species of Hevea is now being extensively grown in the south-western region of the Indian peninsula. The most striking symptoms of the disease are the rotting of the fruit and the wilting and abnormal shedding of the leaves. Mr. McRae describes the external symptoms and the microscopic characters of the affected tissues, and also his experiments on inoculation; the structure and the lifehistory of the fungus are also fully described. The resting spores of the fungus are found in the fruits of the plant, and as the fruits are therefore the chief means of propagating the disease, the possibility is suggested of the destruction of the flowers in order to prevent the formation of fruit. This might be done by mechanically removing the flowers or by spraying them with a chemical that would kill them, but up to the present neither of these means has been found practicable.

\section{THE FISHERIES AND THE INTER- NATIONAL COUNCIL. ${ }^{1}$}

\section{I.}

$\mathrm{I}^{\mathrm{N}}$ former communications ${ }^{2}$ it was shown how insignificant is the influence of man in affecting the plants, such as seaweeds and diatoms, abounding in the sea, and how little he can influence the lower marine animals, from microscopic elementary forms, through sponges, zoophytes, starfishes, annelids, shellfishes, and cuttlefishes, up to fishes. It was further demonstrated in 1898 that the closure of the experimental areas (Forth, St. Andrews Bay, and Aberdeen Bay) had not affected the food-fishes, either as regards increase or diminution in numbers or size. Now it may be asked: Where have the melancholy anticipations of the pessimists been demonstrated; where has the serious diminution of any food-fish occurred; and where have the principles enunciated in "The Resources of the Sea "been traversed by the International Fisheries Council, the most extensive, and certainly the most expensive, combination of fisheries authorities the world has seen, which owed its existence to opinions (viz. those of the impoverishment theory)

\footnotetext{
1 From a lecture given in Aberdeen on March 4 by Prof. McIntosh, F.R.S.

2 Nature, vol. lxxvi., p. zor, rga7.
}

NO. 2592, VOL. IO3] diametrically opposed to those of "The Resources of the Sea"?

In the lectures at the Royal Institution in 1907 the uncertainty of the Fishery Board for Scotland in connection with the further closures than those remitted to it was pointed out, for it had oscillated between an increase and a diminution of fishes in the experimental areas, and its own statistics in subsequent years proved the safety of the Scottish fisheries, which have been dealt with elsewhere up to I912, when they were reviewed at the Dundee meeting of the British Association. No voice at that meeting was raised in support of the impoverishment of the sea, though Dr. Petersen, Dr. Mortensen, and Prof. Jungarsen from Copenhagen, and others specially interested were present. Indeed, Prof. Hulrecht, of Utrecht, aiso present, strongly supported "The Resources of the Sea," and stated that Prof. Huxley held the same views. Since IgI.2 similar prosperous records have been annually published by the Scottish Board up to $19^{1} 3$, the last year unaffected by the war, when the climax was reached, the value of the catch of fishes being no less than 3,997,7 $\mathrm{I} 7$. (or only $2283 l$. less than four millions), the highest value yet attained in the fisheries of Scotland, though the catch of herrings that year had been $75^{8}, 75^{6} \mathrm{cwt}$. below that of the previous one.

The same cause for satisfaction exists after a perusal of the captures, year by year, in such a bay as St. Andrews, where they have been under observation for at least half a century, and in which the pulse of the North Sea is felt day by day and month by month each season, with perhaps varying regularity, producing its fishes in greater or less abundance.

Before going into the results of the costly international scheme, it mav be well to recall the remit made to the Council of that body. It was, in the first place, to benefit the British fisheries, to clear up the discrepancies between "The Resources of the Sea" and "The Impoverishment of the Sea"-in the words of Prof. Garstang: "It was the problem of all nroblems whether the conclusions in this book ['The Resources of the Sea'] were well or inadequately founded." The Council had also to ascertain "whether the quantity and consumption of fish taken from the North Sea and neighbourhood are in proper proportion to the production occurring under the prevailing natural conditions, and whether any disproportion between production and consumption arises from a local over-fishing or from an injudicious employment of the fishing apparatus at present in use." The flat-fish grounds were also to be investigated; annual results published; discoveries of practical importance to the fisheries made, such as "discovering the limit to which fishing grounds can be depleted without undergoing serious injury"; and, finally, recommendations for international action proposed. This formidable remit was, moreover, burdened by a heavy load of hydrographical, physical, chemical, and meteorological observations. Yet some members of the Council guaranteed results for international action within two years-a fact which demonstrates how little the situation was understood.

The earlier work of the International Council was dealt with on a former occasion, and since then the following gives a brief note of its labours:-

Reports on the quantitative distribution of the eggs and larvæ of the cod tribe and of the sardine and anchovy in the North Sea have been given by Hoek; on young salmon by Arwidsson; on the cod by Hoek; nn the herring by Hjort and Lea; on the eel by Schneider: and on the mackerel by Nilsson, all containing additions to our knowledge, though they do not bear on the main question submitted to the International Council for solution. The Council was likewise 